\title{
"Revolutionary Realism and Romanticism": Representing the Ballet The Red Detachment of Women (1971)
}

\author{
Di LIU \\ Foreign Languages Studies, Anshan Normal University \\ No. 43, Ping'an Street, Tiedong District, City of Anshan, Liaoning Province, P. R. China \\ Email: lydia7384@hotmail.com
}

Keywords: Model work, Revolutionary realism and romanticism, Three prominences, Zoom lens.

\begin{abstract}
This paper takes the well-known model work, the ballet The Red Detachment of Women (1971) as a case study to analyze this ballet in relation to the following issues: harmonic music language "Revolutionary Realism and Romanticism", Three Prominences (San tuchu), the relationship between music and image via the use of zoom lens, and so forth. It also examines how the traditional Chinese and European musical-dramatic elements are fitted into a framework of functional harmony reminiscent of the musical idiom of Western romantic music.
\end{abstract}

\section{Introduction}

Since the release of The Red Detachment of Women in 1971, "the ballet has been highly acclaimed for its moving and tragic plot, magnificent stage design, and graceful choreography", and significantly, for its music which "contributes a lot to the ballet's success and popularity" (Mittler, 1997: 47). Here it is relevant to consider whether film music reflects the specific political climate within which it is created, and how it achieves its political goal since it cannot speak to audiences directly. In order to address this question, this paper will take the very well-known modelwork, the ballet The Red Detachment of Women (1971) as a case study to analyze this ballet in relation to the following issues: harmonic music language "Revolutionary Realism and Romanticism", Three Prominences (San tuchu), the relationship between music and image via the use of zoom lens, and so forth. This paper will also examine the use of traditional Chinese and European musical-dramatic elements in depth. Musically, this piece adapts a style, which can be best described by the term "pentatonic romanticism" (Mittler, 1997: 33); elements and quotations from Chinese folk music are fitted into a framework of functional harmony reminiscent of the musical idiom of Western romantic music.

\section{Film Synopsis}

This ballet version Red Detachment of Women is set during the Civil War (1927-1937), in the tropical lushness of Hainan Island on the southern coast of Guangdong (Clark, 1987: 102). It recounts the story of Wu Qinghua, a young servant girl who works for an evil landlord Nan Batian. She tried to escape but was always captured and punished. Nearly beaten to death, she is eventually freed and finds the Red Detachment of Women with the help of Hong Changqing, a party representative in the Red Army. Wu Qinhua joins the army and after Hong is burnt to death by Nan Batian, Wu Qinghua leads her women's detachment and captures the evil landlord, Wu then takes over Hong Changqing's command and continues the battle. 


\section{Musical Characteristic - "Revolutionary Realism and Romanticism"}

\section{Music and Composers}

The brisk and cheerful melody of the ballet The Red Detachment of Women was taken from the first Chinese stage ballet Beautiful Mermaid (1959) (Liang, 1992). The two composers, Du Mingxin and Wu Zuqiang, "had both studied music in the Soviet Union during the 1950s" (Liang, 1992: 270). Thus, we can easily catch the western musical elements and styles in this work, which is one of the first experiments by Chinese artists in creating a national ballet.

Following Beautiful Mermaid, many Chinese musicians and artists became involved in the project of The Red Detachment of Women. It was not until five years later that The Red Detachment of Women was premiered in 1964 in Beijing (Liu, 1982). Barbara Mittler comments that "The Red Detachment of Women is the first successful large-scale Chinese ballet to boast a strong Chinese flavor and style", and "the music, undoubtedly, also contributes a lot to the ballet's success and popularity" (Mittler, 1997: 46).

\section{The Use of Westem Harmony}

In the ballet The Red Detachment of Women, the harmonic language is based on romantic models, working within the boundary of functional harmony, with "quite a few chromatic modulations but restrained (and deliberate) use of dissonance" (Duo, 1983: 7). Because the original melodies were homophonic, it was relatively simple to harmonize them. Moreover, Chinese performance elements are incorporated in this Western musical framework, not only do the actors make use of Beijing opera gestures and poses, but Chinese instruments are also used to add "coloring to the Western orchestra" (Liu, 1982:37).

The simply harmonized orchestral sustained passages in one or two voices are reminiscent of the linear structuring of Chinese music. This general feature is particularly evident in passages where country-dances are quoted or imitated as musical material (Liu, 1982). In most cases, in the ballet The Red Detachment of Women, the Chinese instruments accompany traditional dances. For instance, suona (oboe) sings in the sword dance of the detachment's men; sheng (mouth organ) and pipa (lute) accompany the dance of Nan Batina's maids; suona and sheng are used in a dance of the peasants and soldiers and a dance of the $L i$ minority, and so on. In addition, the song of the peasants presenting their gifts to the communists is similarly based on elements of Chinese folk music. The yangqin accompaniment emphasizes the folkloric atmosphere. It is pentatonic and makes the use of such "idiosyncratic features as the constant repetition of a melodic core", the use of grace notes and unison writing with slight heterophonic elements (Mittler, 1997:47).

In order to convey realism, Du Mingxin, Wu Zuqiang, as well as other composers experimented with some other more recent Chinese traditions. They employed several revolutionary and military songs, which would have been well-known to the contemporary Chinese audiences. For example, the second scene begins with the song of March of the Women's Company:

Forward, forward!

Important the soldiers' task, deep the women's hatred.

Smash your shackles rise in revolution!

We're the Women's Company, taking up arms for the people.

Forward, forward!

Important the soldiers' task, deep the women's hatred. 
Communism is the truth, the Party leads the way.

Slaves will arise, slaves will arise!

The choral parts are written in typical mass song style, accompanied by a limited lyric. Qianjin (Forward), an expression used in many revolutionary songs is repeated three times here. The leitmotif of the Red Detachment typifies the rhythmic and intervallic structure. The fourth jump, the triplets and the typical punctuated rhythm continue to dominate the entire piece (Mittler, 1997).

\section{Leitmotif-technique}

A leitmotif-technique is used throughout the ballet The Red Detachment of Women to facilitate easy recognition of certain characters. First of all, the leitmotif of the March of the Women's Company is very simple in terms of rhythm, being in the style of military music, which has to be easily sung and played while marching. A good example of this is the second scene of the model ballet where the image of the Red Detachment comes towards the viewer directly, straight and bravely. The music and image relationship here is synchronised vividly.

Secondly, a much more complex leitmotif in The Red Detachment of Women is composed for our heroine $\mathrm{Wu}$ Qinghua. As she is first seen in a situation of extreme anger, hanging in the chains of her cruel employer, the evil landlord Nan Batian, her theme starts off with a "desperate but strong-willed", accented fourth jump, "ascending", "breaking off and again discharging its energy in the triplets", repeated with an even higher octave jump (Mittler, 1997: 88). The violin plays both high strings and base to introduce her motif with the low strings trembling (for her) in a tremolo.

Another heroic theme introducing Hong Changqing comes in one of the next scenes. In contrast to the lower pitch instruments used for the evil characters, the high strings, flute and clarinet play his leitmotif. "The accented syncope emphasizes his vigour, which is further supported by the fragmentation of the motivated parts into smaller and smaller, and higher and higher elements, a method that creates a sense of energetic urgency" (Mittler, 1997: 90).

Thirdly, in order to reflect the dramatic situation, these leitmotifs are modified and varied and sometimes combined in interesting ways. For the importance of music as an aid to the emotional experience in classical narrative film, Kethryn Kalinak's argument regarding the role of music as "the most efficient code" for emotional expression is a strong one (Kalinak, 1992: 87). Simultaneously, she also argues that of both the representation and the elicitation of feeling play a very important role in the relevant film. Therefore, the leitmotif-technique in the ballet The Red Detachment of Women is important not only for helping audiences to recognize certain characters, but also, as film-music composition it evokes a strong emotional identification with class, especially to audiences in the Cultural Revolution era.

\section{Non-musical Characteristics}

\section{Three Prominences - San tuchu}

In his Talks at the Yanan Forum on Forum on Literature and Art, Mao Zedong was inspired by Stalinist Soviet aesthetic theories. He stated that: 'Literature and art can and ought to be on a higher plane, more intense, more concentrated, more typical, nearer the ideal, and therefore more universal than everyday life" (Mao, 1967: 82; also cited in McDougall, 1980: 70). However, this was a move away from naturalism. Similarly, after 1958, the fashionable cultural slogan of "combining Revolutionary Realism and Revolutionary Romanticism" was not 
only anti-naturalistic but allowed for greater acknowledgement of national aesthetic modes, from opera and elsewhere (Wang, 2006: 6). Since then, audiences, film artists, and even Ministry of Cultural officials have repeatedly lamented the formalism and reliance on stereotypes produced in films of the Cultural Revolution period. Thus, the Cultural Revolution Model Works techniques, under the influence of Jiang Qing, show a single-minded concentration on the Three Prominences (San tuchu).

In the Red Detachment of Women, San tuchu is practiced through clothes and the colours of the characters. Firstly, although Jiang Qing was not the creator of the model works, she was the most important decision maker regarding their purpose and style. Jiang Qing hated existing "bourgeois" ballets such as Swan Lake, which she characterized as being: "full of birds and beast" (Jiang, 1974: 25). In her opinion, ballets should be filled with human heroism and will (Wu, 1969, 5: 82). Furthermore, Jiang Qing felt it was necessary to be wary of the formalist dangers of this foreign art form; in particular, when the aesthetic style was considered more important than the ideological message. Hence, Jiang Qing made her dancers live with army units so they could better describe war and struggle in their movements and facial expressions. It is also worth noting that in the ballet the women's uniforms are even cleaner and greener than in the same feature film produced in 1964.

Secondly, Hong Changqing, the Party representative and male hero, is made more prominent by practicing San tuchu. An important element which emphasizes the heroism and importance of Hong Changqing is the use of colour. When Hong Changqing visits Nan Batian on his birthday in scene one, Hong himself is disguised as a noble overseas Chinese man; he appears in red and bright lights to contrast sharply with the Tyrant of the South who is cast in cold grey. Similarly, when Hong Changqing is wounded in scene four, a triumphant red glow brightens his face. The same red light crowns him when he stands, head high and defiant on the execution ground. The luxuriant ancient tree, under which he eventually meets his death, is also wrapped in red light, and also serves the purpose of the San tuchu at the same time.

\section{The Use of the Zoom Lens}

Willemen's arguments are applicable to Chinese Cultural Revolutionary Model Works. For example, as noted earlier, Jiang Qing was influenced by Western films in the 1960s, she was also unsatisfied with the extensive use of zoom lens in the model work Taking Tiger Mountain by Strategy (1970).

What Willemen refers to as the importance of the pre-modern in films, lies in "its feudal honours system and monarchy" (Willemen, 2002: 11). Although Willemen does not mention the situation in contemporary Chinese cinema, the situation during the Cultural Revolution reflects his claims as a whole. For instance, in accordance with Mao Zedong's directive "To weed through the old to create the new and through the Western to create a Chinese national art" (McDougall, 1980:3), Jiang Qing demanded that "many traditional operas had a didactic purpose, and each was chosen to fulfil a function in the model works" (Jiang, 1974: 25).

Therefore, certain facial make-up, costumes, movements, language and musical accompaniment which would indicate negative and positive characters in the traditional operas, have been adopted in the model works in order to better adhere to some of these traditional symbols (Denton, 1987: 119-123). Willemen also points out that the zoom displays recognition within the filmic discourse, or implies recognition of presence for the audience. Thus, it is important and necessary to further understand and research the development of Chinese cinema as a new technological language. 


\section{The Synchronised Relationship between Music and Image}

Due to Jiang Qing's insistence on control of the use of zoom lens, the model ballet The Red Detachment of Women was made as a musical celluloid version in 1971, using camera angles and shots which are really simple and easy to be understood by the audiences. For example, the camera height is always at eye-level and follows the characters' movements from the very beginning to the end of the show. Moreover, almost half of the film is made up of long shots, as if an audience is sitting in the theatre and watching the ballet itself.

As a result, both the use of camera angle and the zoom lens control have limited the relationship between music and image in terms of range. During the Cultural Revolution period, it is obvious that the relationship between music and image in the model works is reductive, especially in the ballet The Red Detachment of Women. This typical music and image interaction from The Red Detachment of Women, which was quite popular with Chinese audiences since it was released in 1971, shows how rare it is to find more than two kinds of partnership working together in Chinese cinema (model works). The synchronised relationship between music and image is incorporated into the film image.

Here is an example from scene two, when Wu Qinghua finds the Red Detachment with the help of the representative of the Communist Party Hong Changqing. With the violin playing $\mathrm{Wu}$ Qinghua's leitmotif, the close up shot shows that Wu Qinghua has tears on her face when she eventually finds the red flag of the Communist Party. Although it is a ballet without any dialogue, audiences can still follow the plot and understand that she might tell herself at the moment: "Oh, my red flag (the symbol of the Chinese Communist Party), I have found you eventually." This image was also highlighted and emphasized by the Chinese Central Government and its significance drawn to the attention of all the audiences in China during the Cultural Revolution period.

\section{Conclusion}

The Red Detachment of Women plays a significant role in the development of Chinese ballet. As one of the model works during the Cultural Revolution, it is also a typical example of work by Chinese artists when combining European ballet with Chinese characteristics. The entire music is conceived within the model work formula so that the political messages of the piece can be easily understood. Musically speaking, the most direct appeal in The Red Detachment of Women is its extensive use of musical-iconographic writing. Other supportive factors within the ballet acting include the set and the lighting to convey a powerful political message. Moreover, due to Jiang Qing's insistence on control of the use of zoom lens, the relationship between music and image becomes reactive. This becomes clear if we compare the model works with the 1950's Chinese cinema where the relationship between music and image is not only synchronised but parallel.

\section{References}

[1] Jiang, Qing, Tan Jingju geming (On the Revolution of Beijing Opera), Hongqi, No.7 (1974) 25

[2] Wang, Hui, Depoliticized Politics, From East to West, New Left Review, (September -October), No.11 (2006) 6 
[3] Willemen, Paul, The Zoom in Popular Cinema: A Question of Performance, Inter-Asia Cultural Studies, NC-JCF (1) Intellect Ltd. (2002) 11

[4] Wu, Yi, A Great Victory in "Making Foreign Things Serve China", CF, 5 (1969) 82

[5] Clark, Paul, The Cultural Revolution, 1964-1978, in Paul Clark Chinese Cinema: Cultural and Politics Since 1949, Cambridge: Cambridge University Press, 1987, p. 102

[6] Denton, Kirk A., Model Drama as Myth: A Semiotic Analysis of Taking Tiger Mountain by Strategy, in Constantine Tung et al. (Ed.) Drama in the People's Republic of China, Albany: State University of New York Press, 1987, pp.119-123

[7] Duo, Tan Du Mingxin de Changdi Shuqin Erchongzou, in Barbara Mittler, Dangerous Tunes: The Politics of Chinese Music in Hong Kong, Taiwan and the People's Republic of China since 1949, Wiesbaden: Harrassowitz, 1983, p. 7

[8] Kalinak, Kathryn, John Williams and "The Empire"Strike Back the Eighties and Beyond: Classical Meets Contemporary', in (Ed.) Setting the Score: Music and the Classical Hollywood Film, Madison: University of Wisconsin Press, 1992, p.87

[9] Liang, Erhei, A Perspective on Selected Compositions, D.M.A. thesis, Louisiana: Louisiana State University, 1992, p. 270

[10] Liu, Terence, Music of Modern Revolutionary Chinese Opera: A Study of Political Influences and Artistic Incorporation, M.A. thesis, Hawaii: University of Hawaii Press, 1982, p. 37

[11] Mao, Zedong, Talks at the Yanan Forum on Forum on Literature and Art, in Selected Works of Mao Zedong, Peking: Foreign Languages Press, Vol. III, 1967, p. 82

[12] McDougall, Bonnie S., Mao Zedong's "Talks at the Yanan Conference on Literature and Art”, Ann Arbor: Michigan University Press, 1980, p. 3, 70

[13] Mittler, Barbara, Dangerous Tunes: The Politics of Chinese Music in Hong Kong, Taiwan and the People's Republic of China since 1949, Wiesbaden: Harrassowitz, 1997, p. 33, 46, $47,88,90$ 